\title{
ローレンツカを用いたセルフベアリングモータの逆起電カを利用した 回転角度推定
}

神川 和也 ${ }^{* 1}$, 上野 哲 ${ }^{* 2}$

\section{Rotational angle estimation of Lorentz-type self-bearing motor using back-EMF}

\author{
Kazuya KAMIKAWA ${ }^{* 1}$ and Satoshi UENO ${ }^{* 2}$ \\ ${ }^{*_{1},{ }^{2}}$ Department of Mechanical Engineering, Ritsumeikan University \\ 1-1-1 Nojihigashi, Kusatsu-shi, Shiga, 525-8577, Japan
}

\section{Received 13 March 2014}

\begin{abstract}
Magnetic bearing motors have the advantages of no friction loss, no lubrication, and so on. However, these motors are not used widely because of their high cost and large size. To overcome these limitations, a self-bearing motor having a simple structure with distributed windings has been proposed. The rotor consists of a permanent magnet and an iron yoke that rotates within the body. The stator consists of two six-phase distributed windings and is installed between the permanent magnet and the back yoke of the rotor. A Lorentz force, generated by the interaction between the stator current and the magnetic field of the permanent magnet, controls the rotational speed and radial position of the rotor. The motor had used hall sensors to detect the rotational angle. In this paper, a sensorless controller without hall sensors is introduced. Finally, the performance of the controller is verified with rotational tests.
\end{abstract}

Key words : Rotary machinery, Active magnetic bearing, Self-bearing motor, Lorentz force

\section{1. 緒言}

磁気軸受は , 摩擦磨耗が無く高速回転が可能 , 潤滑油を必要としないため真空中や極低温といった環境でも使用 可 , 軸の振動制御など高性能な軸の支持が可能といった多くの利点を有している (日本機械学会編，1995)．しか し，高価である，軸受力が小さい，装置が大型化するなどの問題により，広く普及するに至ってはいない，近年， 小型モ一タの高性能化, 高付加価值化の要求が高まっており, 弚のための磁気軸受の小型化 , 低価格化か望まれて いる (Kanebako and Okada, 2002)（上野，荒川，2011）(黑野他，2003）．

現在 ，小型モータとして $2 \mathrm{~mm}$ スロットレスモータが市販されている (並木精密宝石株式会社 ，2012）．このモ一 久構造を利用することで小型の磁気軸受やセルフベアリングモータを実現することができる．乥こでスロットレ スモータと同樣の分布巻線をステータに配置し，ローレンツカによって軸受力と回転トルクを同時に独立して発 生させるセルフベアリングモータを提案した（上野，荒川，2011）.試作機の浮上回転試験では，ロータの回転位 置を用いてステータ電流を計算することで, 位置制御性能が向上することが確認できた . 試作機では回転角位置 の検出にホールセンサを用いたが , ホールセンサは電子部品のため熱や振動に弱く機械的信頼性が低いため，セ ンサを用いないセンサレスか強く望まれている．また，センサを取り除くことでモータのさらなる小型化，低価 格化が期待できる .

近年，樣々な回転角度センサレス制御法か提案されている.センサレス制御法では，誘起電圧を用いた方法 (黑

\footnotetext{
No. 14-00145 [DOI: 10.1299/transjsme. 2014dr0236]

${ }^{* 1}$ 正員, 立命館大学大学院（干525-8577 滋賀県草津野路東 1-1-1）

*2 正員, 立命館大学理工学部

E-mail of corresponding author: sueno@se.ritsumei.ac.jp
} 


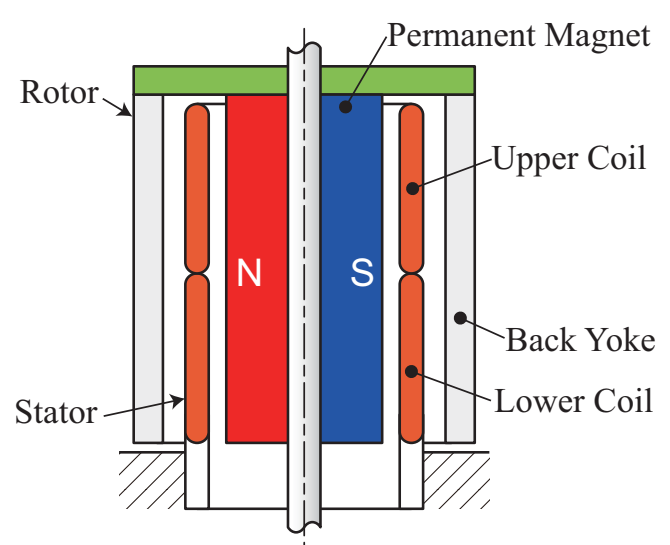

Fig. 1 Structure of the self-bearing motor. The back yoke is fixed to the permanent magnet of the rotor to avoid unstable magnetic force.

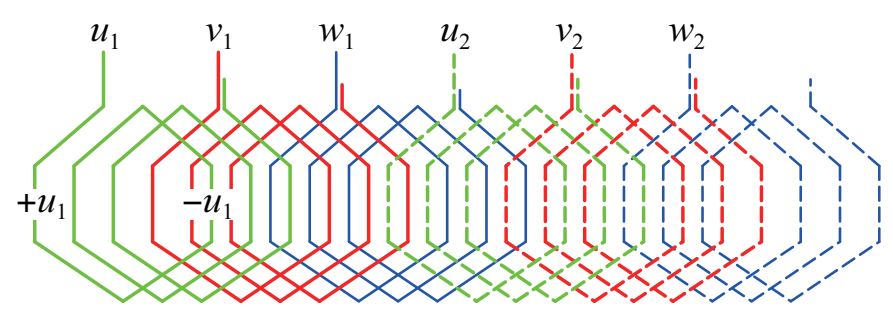

Fig. 2 Developed view of the stator windings. The interval between neighboring phases is 60 degrees. The interval between plusphase and minus-phase is 90 degrees.

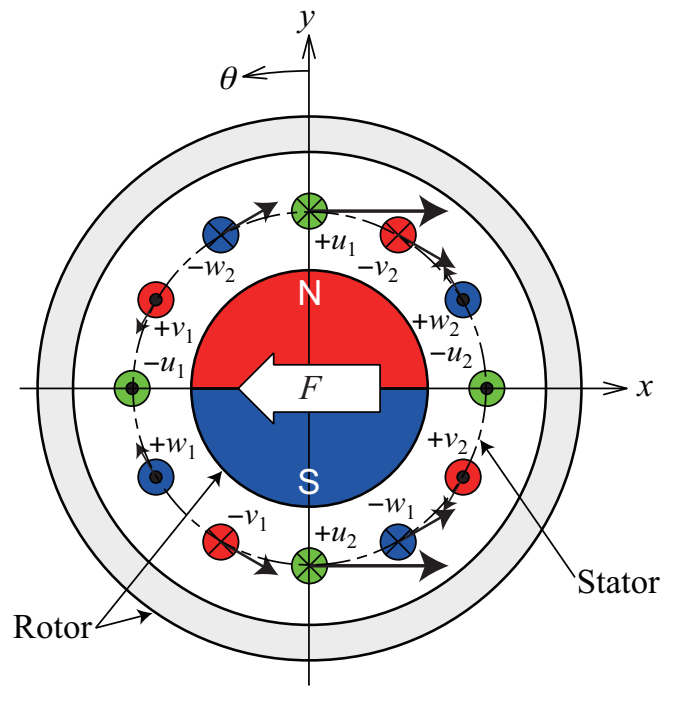

Fig. 3 Generation of radial force. Lorentz forces and bearing force $F$ are denoted by black and white arrows, respectively.

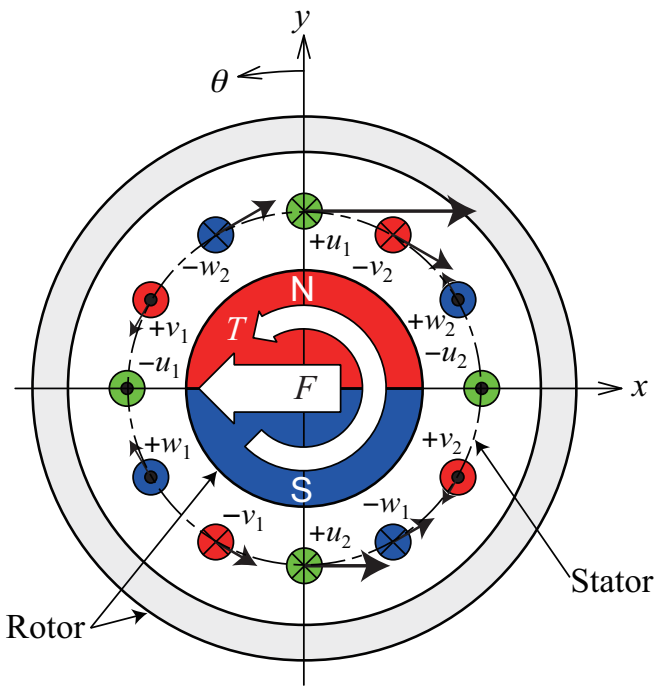

Fig. 4 Generation of radial force and torque. Torque $T$ is denoted by a rounded white arrow.

野他，2003），適応才ブザーバによる方法 (星野，伊藤，2008），V/f 制御（伊東他，2002）などか提案されてい る.今回は誘起電圧を用いた方法を採用し，ステータ巻線の電圧，電流值から回転角度を推定するセンサレス制 御を行った . 本論文では , 回転角位置の推定方法と試作機での浮上回転試験の結果を報告する .

\section{2. セルフベアリングモータ}

本論文で提案するセルフベアリングモータの構造を図 1 に示す . ロータにはラジアル着磁された 2 極の円筒型 永久磁石を用いる . 永久磁石によるラジアル方向の不安定力をなくすため, 永久磁石とバックヨークを一体化した 構造とする . ステータ巻線は, 永久磁石とバックヨークの間の隙間に挿入される.2つのステータ巻線でロータの ラジアル 4 自由度の位置制御と回転制御を行う．ステータ巻線は, 空芯の 6 相分布巻線を用いる . 图 2 にステー タ巻線の展開图を示す . 隣り合う相の間隔が 60 度 , 各相のプラスとマイナスの間隔が 90 度となるように導線を 配置する

軸受力の発生原理を図 3 に示す . ステータに図のように 3 相電流を流すと，ギャップ磁界と電流の相互作用によ り，巻線に矢印で示されるようなローレンツカが発生する. 巻線はステータに固定されているため光の反力とし てロータのラジアル方向に軸受力 $F$ が発生する . またトルク発生原理を図 4 に示す．トルク発生用の 3 相電流を 


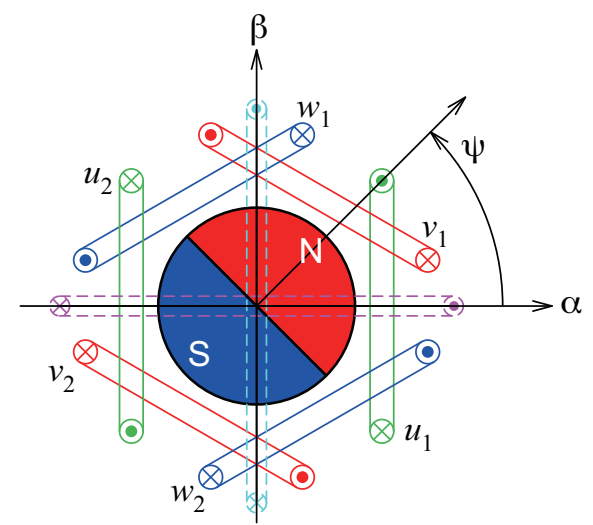

Fig. 5 Coordinate system of stator windings. The direction of the magnetic flux generated by $u_{1}$ and the orthogonal direction of it are defined as $\alpha$ and $\beta$, respectively. The angle between the $\mathrm{N}$ pole of the rotor and $\alpha$ is denoted by $\psi$.

$u_{1}, v_{1}, w_{1}$ 相に加算， $u_{2}, v_{2}, w_{2}$ 相に減算することで対向する巻線でローレンツカに差が生じ，回転トルク $T$ が発生 する．ラジアル方向の合力は変わらないため，位置制御とトルク制御を同時に行うことが出来る．

ステータ巻線の電流 $i_{u 1}, i_{u 2}, i_{v 1}, i_{v 2}, i_{w 1}, i_{w 2}$ は次式で表される.

$$
\begin{aligned}
& i_{u 1, u 2}=i_{x} \sin \left(\psi+\theta_{0}\right) \quad+i_{y} \cos \left(\psi+\theta_{0}\right) \quad \pm i_{m} \cos \left(\psi+\theta_{0}+\pi / 4\right) \\
& i_{v 1, \nu 2}=i_{x} \sin \left(\psi+\theta_{0}-2 \pi / 3\right)+i_{y} \cos \left(\psi+\theta_{0}-2 \pi / 3\right) \pm i_{m} \cos \left(\psi+\theta_{0}+\pi / 4-4 \pi / 3\right) \\
& i_{w 1, w 2}=i_{x} \sin \left(\psi+\theta_{0}-4 \pi / 3\right)+i_{y} \cos \left(\psi+\theta_{0}-4 \pi / 3\right) \pm i_{m} \cos \left(\psi+\theta_{0}+\pi / 4-2 \pi / 3\right)
\end{aligned}
$$

ここで $i_{x}, i_{y}$ は $x, y$ 方向の位置制御電流， $i_{m}$ はトルク制御電流， $\psi$ はロータの回転角度,$\theta_{0}$ は巻線の位置のずれを 表す．

\section{3. 逆起電力による回転角度推定方法}

次に回転角度の推定方法について述べる .ここでは簡単のため, ステータ巻線の配置か理想的で, 各相の自己 インダクタンスが同じ值であると仮定する．また試作機の各相の抵抗值にばらつきがあったため，抵抗值の違い を考慮に入れ，回転角度推定方法を考える．

図 5 のように座標系を定める. $u_{1}$ 相の巻線により作られる磁束の向きに $\alpha$ 軸，弚れに直交する方向に $\beta$ 軸を定 める.ロータの $N$ 極の向きと $\alpha$ 軸の角度を $\psi$ とする .

ステータ巻線の電圧 $\mathrm{v}$ と電流 $\mathrm{i}$ の関係は

$$
\mathbf{v}=\mathbf{R i}+\frac{d}{d t} \mathbf{L i}+\mathbf{v}_{b}
$$

となる こここで

$$
\begin{aligned}
& \mathbf{v}=\left[\begin{array}{llllll}
v_{u 1} & v_{v 1} & v_{w 1} & v_{u 2} & v_{v 2} & v_{w 2}
\end{array}\right]^{T} \\
& \mathbf{i}=\left[\begin{array}{llllll}
i_{u 1} & i_{v 1} & i_{w 1} & i_{u 2} & i_{v 2} & i_{w 2}
\end{array}\right]^{T} \\
& \mathbf{R}=\operatorname{diag}\left(R_{u 1}, R_{v 1}, R_{w 1}, R_{u 2}, R_{v 2}, R_{w 2}\right)
\end{aligned}
$$

$$
\mathbf{L}=\frac{L}{2}\left[\begin{array}{cccccc}
2 & 1 & -1 & -2 & -1 & 1 \\
1 & 2 & 1 & -1 & -2 & -1 \\
-1 & 1 & 2 & 1 & -1 & -2 \\
-2 & -1 & 1 & 2 & 1 & -1 \\
-1 & -2 & -1 & 1 & 2 & 1 \\
1 & -1 & -2 & -1 & 1 & 2
\end{array}\right]
$$


であり， $R$ は添字の相の抵抗值,$L$ は自己インダクタンスを表す. $\mathbf{v}_{b}$ は巻線に生じる逆起電力を表し , ロータの変 位が小さい場合は変位の影響を無視し，

$$
\mathbf{v}_{b}=\frac{d}{d t}\left[\begin{array}{c}
\varphi_{u 1} \\
\varphi_{v 1} \\
\varphi_{w 1} \\
\varphi_{u 2} \\
\varphi_{v 2} \\
\varphi_{w 2}
\end{array}\right]=\frac{d}{d t}\left[\begin{array}{c}
\varphi_{m} \cos \psi \\
\varphi_{m} \cos (\psi-\pi / 3) \\
\varphi_{m} \cos (\psi-2 \pi / 3) \\
\varphi_{m} \cos (\psi-\pi) \\
\varphi_{m} \cos (\psi-4 \pi / 3) \\
\varphi_{m} \cos (\psi-5 \pi / 3)
\end{array}\right]=-\dot{\psi} \varphi_{m}\left[\begin{array}{c}
\sin (\psi) \\
\sin (\psi-\pi / 3) \\
\sin (\psi-2 \pi / 3) \\
\sin (\psi-\pi) \\
\sin (\psi-4 \pi / 3) \\
\sin (\psi-5 \pi / 3)
\end{array}\right]
$$

と近似する．ここで $\varphi$ は鎖交磁束を表し， $\varphi_{m}$ は鎖交磁束の波高値を表す．

$\mathrm{A} / \mathrm{D}$ 变換器の数を減らすため, $120^{\circ}$ 間隔にある巻線 $u_{1}, w_{1}, v_{2}$ 相の端子電圧を用いて角度推定を行う.コイル電 圧を $\alpha-\beta$ 座標に変換するため, 以下の変換行列 $\mathbf{T}$ を用いる .

$$
\mathbf{T}=\left[\begin{array}{cccccc}
1 & 0 & -1 / 2 & 0 & -1 / 2 & 0 \\
0 & 0 & \sqrt{3} / 2 & 0 & -\sqrt{3} / 2 & 0
\end{array}\right]
$$

式(4)に左から T を掛けて整理すると

$$
\begin{gathered}
-\frac{3}{2} \dot{\psi} \varphi_{0} \sin (\psi)=\left(v_{u 1}-\frac{v_{w 1}}{2}-\frac{v_{v 2}}{2}\right)-\left(R_{u 1} i_{u 1}-\frac{R_{w 1} i_{w 1}}{2}-\frac{R_{v 2} i_{v 2}}{2}\right)-\frac{3 L}{2} \frac{d}{d t}\left(i_{u 1}+\frac{i_{v 1}}{2}-\frac{i_{w 1}}{2}-i_{u 2}-\frac{i_{v 2}}{2}+\frac{i_{w 2}}{2}\right) \\
\frac{3}{2} \dot{\psi} \varphi_{0} \cos (\psi)=\frac{\sqrt{3}}{2}\left(v_{w 1}-v_{v 2}\right)-\frac{\sqrt{3}}{2}\left(R_{w 1} i_{w 1}-R_{v 2} i_{v 2}\right)-\frac{3 L}{2} \frac{d}{d t}\left(\frac{\sqrt{3}}{2} i_{v 1}+\frac{\sqrt{3}}{2} i_{w 1}-\frac{\sqrt{3}}{2} i_{v 2}-\frac{\sqrt{3}}{2} i_{w 2}\right)
\end{gathered}
$$

となる.上式の左辺は, 逆起電力の $\alpha, \beta$ 成分を表す. これらを $v_{b \alpha}, v_{b \beta}$ とすると, 逆起電力は次式より求めるこ とができる .

$$
\left[\begin{array}{l}
v_{b \alpha} \\
v_{b \beta}
\end{array}\right]=\mathbf{T}_{v}\left[\begin{array}{l}
v_{u 1} \\
v_{w 1} \\
v_{v 2}
\end{array}\right]-\mathbf{T}_{R} \mathbf{i}-\frac{d}{d t} \mathbf{T}_{L} \mathbf{i}
$$

ただし

$$
\begin{aligned}
& \mathbf{T}_{v}=\left[\begin{array}{ccc}
1 & -1 / 2 & -1 / 2 \\
0 & \sqrt{3} / 2 & -\sqrt{3} / 2
\end{array}\right]
\end{aligned}
$$

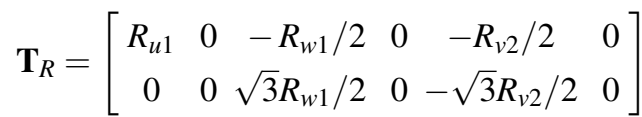

$$
\begin{aligned}
& \mathbf{T}_{L}=\frac{3 L}{2}\left[\begin{array}{cccccc}
1 & 1 / 2 & -1 / 2 & -1 & -1 / 2 & 1 / 2 \\
0 & \sqrt{3} / 2 & \sqrt{3} / 2 & 0 & -\sqrt{3} / 2 & -\sqrt{3} / 2
\end{array}\right]
\end{aligned}
$$

である .これよりロータの回転角は次式より推定できる .

$$
\psi=\tan ^{-1}\left(-\frac{v_{b \alpha}}{v_{b \beta}}\right)
$$

\section{4. 実 験 装 置}

\section{$4 \cdot 1$ 試験機の構造}

実際にセンサレス制御が可能かどうか実験により検証を行った . 実験に使用した装置を図 6 に示す．ロータの アキシャル方向は，カップリングにより支持し，ロータのラジアル方向の 2 自由度のみ制御を行う．ロータ上部， 下部弚れ光れに $x, y$ 方向の変位を検出する渦電流式変位センサ (キーエンス : EX-500) を計 4 つ設置し, ラジア ル方向のロータ変位を計測する . 実際のロータの回転角度を検出するために軸上部にロータリーエンコーダ (コ パル：RE30E) を取り付けた . 


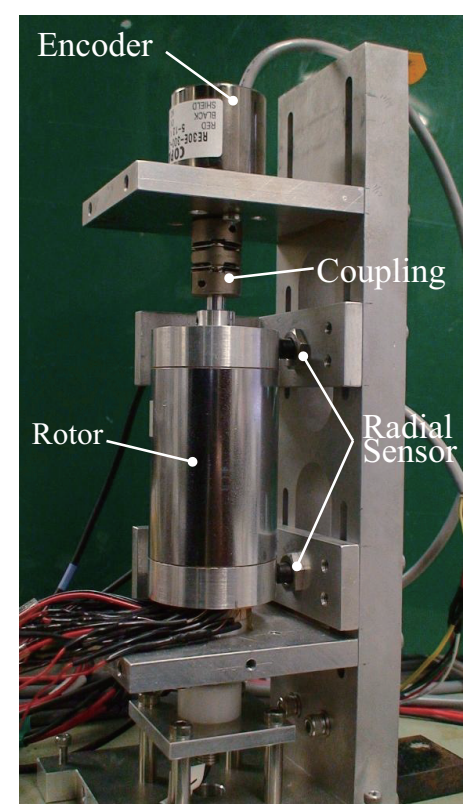

Fig. 6 Test rig for sensorless controller. $x$ and $y$ directions are detected by eddy current displacement sensors. A rotary encoder is attached to above the rotor to detect a real angle.

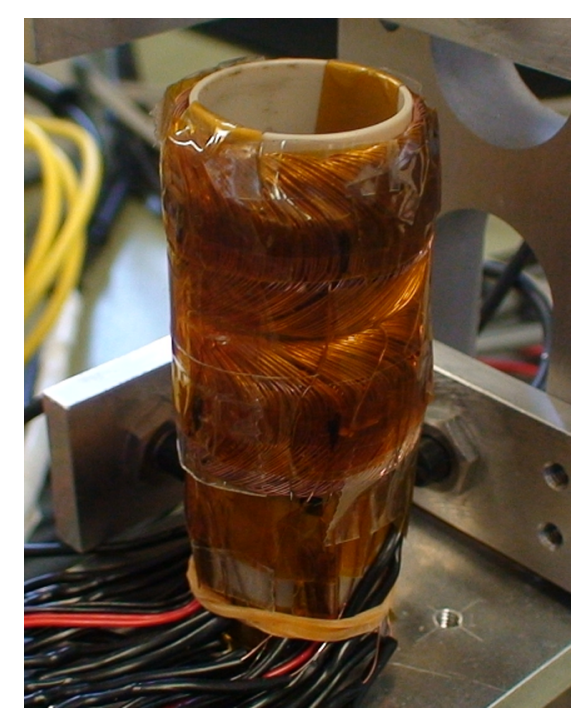

Fig. 7 Stator windings. The stator is inserted into the gap between the back yoke and the permanent magnet.

Table 1 Parameters of the controllers.

\begin{tabular}{lcc}
\hline & Radial (PID) & Speed (PI) \\
\hline Proportional Gain & $2000 \mathrm{~A} / \mathrm{m}$ & $1000 \mathrm{~A} / \mathrm{rpm}$ \\
Integral Gain & $450 \mathrm{~A} /(\mathrm{m} \mathrm{s})$ & $500 \mathrm{~A} /(\mathrm{rpm} \mathrm{s})$ \\
Differential Gain & $12 \mathrm{~A} /(\mathrm{m} / \mathrm{s})$ & - \\
Differential Time Constant & $0.3 \times 10^{-3} \mathrm{~s}$ & - \\
\hline
\end{tabular}

ロータは，2 極の円筒型永久磁石とバックョーク，軸などで構成されている . 永久磁石には外径 $22 \mathrm{~mm}$, 内径 $8 \mathrm{~mm}$ ，長さ $46 \mathrm{~mm}$ のネオジム磁石を用いた . バックョークは S45C を用い，外径 $38 \mathrm{~mm}$ ，内径 $24 \mathrm{~mm}$ ，長さ $51 \mathrm{~mm}$ とした .コイル位置での磁束密度の波高値は約 $0.6 \mathrm{~T}$ となった .

ステータの写真を図 7 に示す . ステータは永久磁石とバックョークの隙間に挿入される . ステータコイルは上 下に二つ設置し，線径 $\phi 0.26 \mathrm{~mm}$ のエナメル線を一相 57 巻したものを製作した . ステータコイル軸方向の長さは

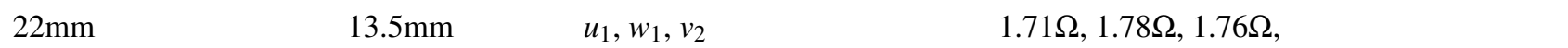
は $70 \mu \mathrm{H}$ となった .

\section{$4 \cdot 2$ 制御システム}

図 8 に装置全体の制御システムを示す .コントローラにはデジタルシグナルプロセッサ (DSP, dSPACE: DS1104) を用いた . ステータ上側の渦電流変位センサ出力を $x_{1}, y_{1}$, ステータ下側の渦電流変位センサ出力を $x_{2}, y_{2}$ とする. 今回は, ステータ下側の渦電流変位センサ出力から上側のステータ巻線のみで孚上・回転制御と回転角推定を行っ た . 角度推定に用いる $u_{1}, w_{1}, v_{2}$ 相の電圧は, 駆動回路と絶縁させるために電圧センサ (LEM: LV25-P) を使用し て測定し，AD コンバータを通して DSP に取り込んだ . 電流值はコントローラ内の指令值を使用した . エンコー ダの信号は，Up/Down カウンタによりDSP に取り込んだ .

DSP からは, DA コンバータのチャンネル数を低減するため, 位置制御電流の U 相と V 相 , モ一タ電流の U 相 と V 相のみを出力する . 出力された各電流の指令值はアナログ演算回路により，式 (18) (20) の計算を行い , パ ワーアンプに出力する . パワーアンプには , パワーオペアンプ (Burr-Brown: OPA548) を用い , 電流フィードバッ 


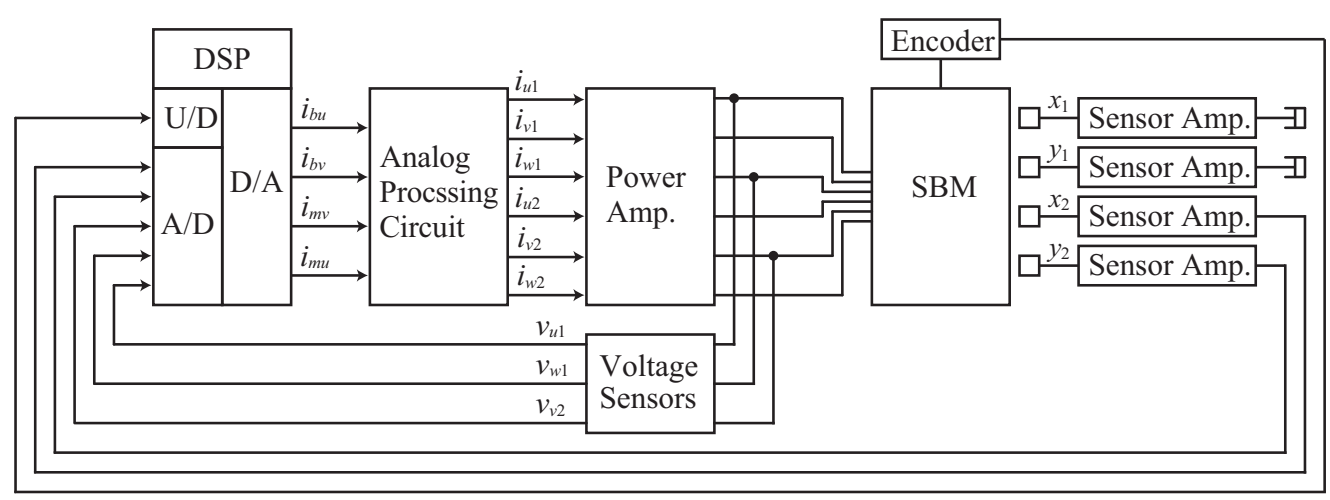

Fig. 8 Control System. A Digital Signal Processor is used for control. To reduce the number of channels of the D/A converters, eqs. (18) (20) are calculated by analog circuits. Voltage sensors are used to insulate the drive circuit.

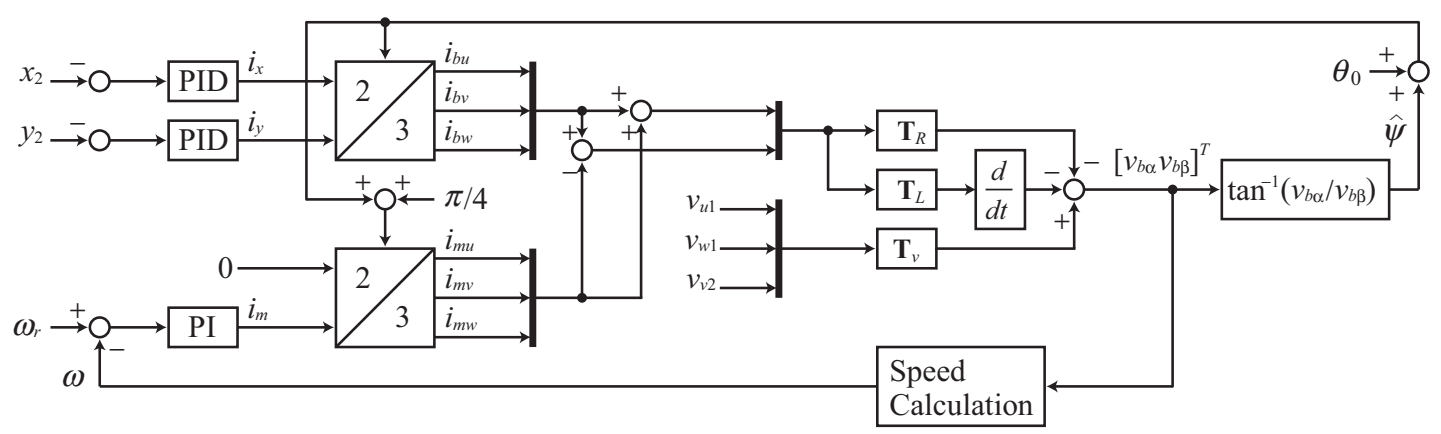

Fig. 9 Sensorless controller. Position control currents are calculated by the PID controller from the outputs of the eddy current displacement sensors, and they are converted from two-phase to three-phase. Rotating speed is calculated from the time of one rotation. PI controller is used for the speed control.

クにより指令された電流をコイルに出力する．

$$
\begin{array}{ll}
i_{u 1}=i_{b u}+i_{m u} & i_{u 2}=i_{b u}-i_{m u} \\
i_{v 1}=i_{b v}+i_{m v} & i_{v 2}=i_{b v}-i_{m v} \\
i_{w 1}=\left(-i_{b u}-i_{b v}\right)+\left(-i_{m u}-i_{m v}\right) & i_{w 2}=\left(-i_{b u}-i_{b v}\right)-\left(-i_{m u}-i_{m v}\right)
\end{array}
$$

図 9 にセンサレス制御のコントローラを示す . 渦電流式変位センサから検出された変位から PID コントローラ で位置制御電流を計算し，2 相 3 相変換で位置制御電流を計算する。

トルク制御電流 $i_{m}$ は実際の角速度と目標の角速度の差から PI コントローラを用いて計算する . 回転速度 $\omega$ は， $v_{b \alpha}, v_{b \beta}$ から一回転に要する時間を計測することで算出した $\cdot v_{b \alpha}, v_{b \beta}$ か設定した閾值をまたいでから再び同方向 にまたぐまでの時間を計測する．今回，コントローラの処理容量の関係から閾値を $v_{b \alpha}$ の 0 に対して上昇時のみ， つまりロータが 360 度回転する毎に角速度を算出するようにした．

実験に用いた各コントローラのゲインを表 1 に示す .

\section{5. 実 験 結 果}

\section{$5 \cdot 1$ コイルの逆起電力}

まず逆起電力の測定結果を図 10 に示す.これは上側コイルの端子を開放し，下側コイルにより位置制御と回転 制御を行った場合の上側コイルの電圧 (上側コイルの逆起電力) を測定したものである．下側センサの情報で位 置制御を行い, 回転数は 2000rpm および 8000rpm とした . 図の実線か測定結果 , 破線か理想的な三相電圧の波形 である .これらの結果から逆起電力か理想的な三相電圧とほぼ一致することが確認できた . 

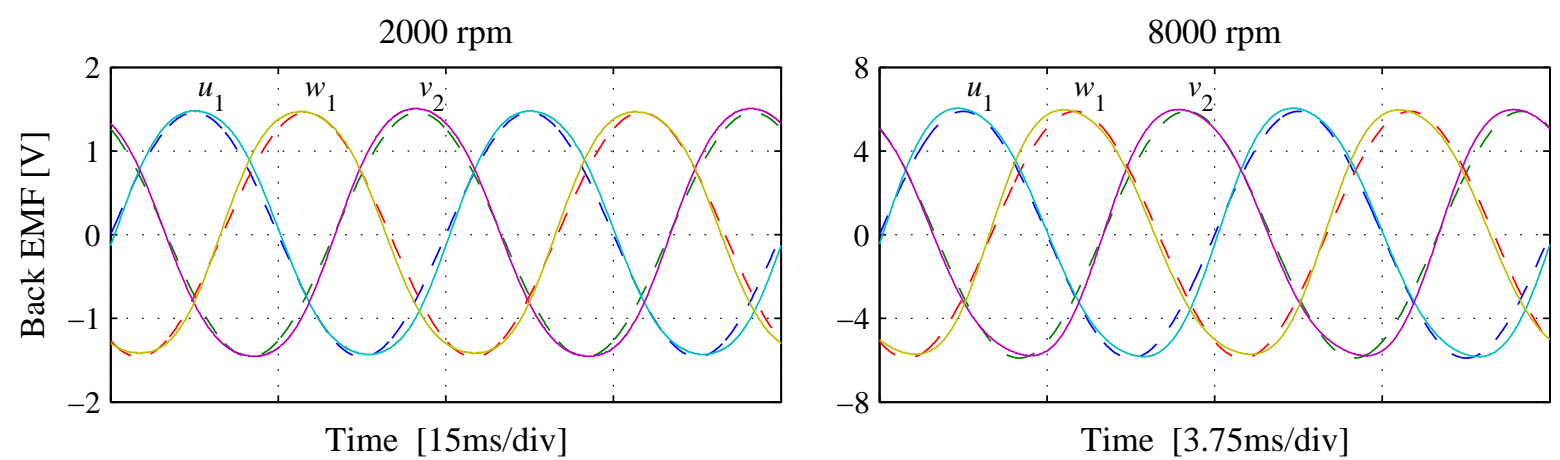

Fig. 10 Measurement results of Back EMF at $2000 \mathrm{rpm}$ and $8000 \mathrm{rpm}$. Measured value and ideal value are plotted with the solid and dashed lines, respectively.

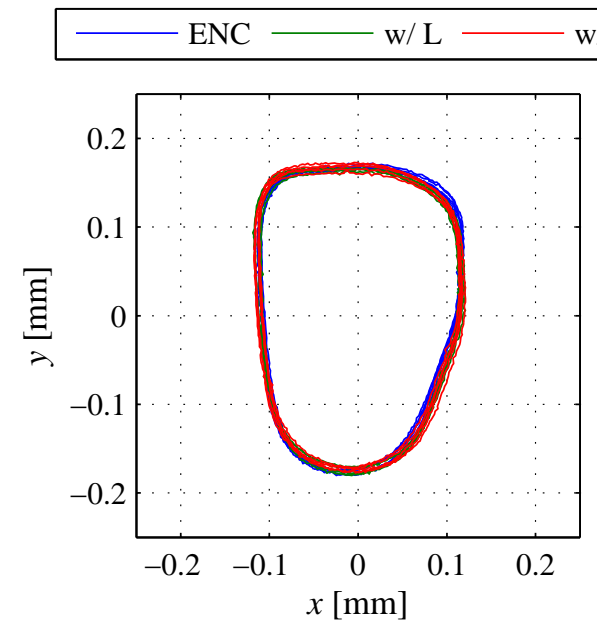

(a) $2000 \mathrm{rpm}$

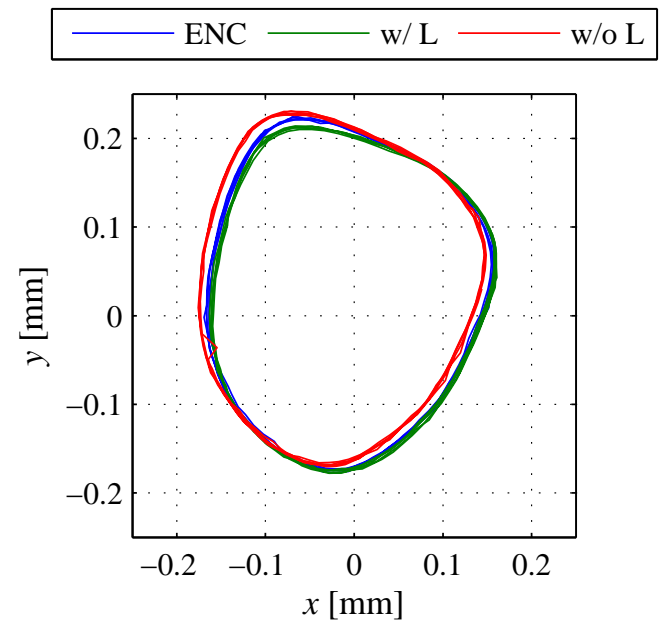

(b) $8000 \mathrm{rpm}$

Fig. 11 Trajectories of the rotor displacement using encoder and sensorless controllers (with and without the inductance term).

Table 2 Mean and root mean square of estimated errors.

\begin{tabular}{c|cc|cc}
\hline \multirow{2}{*}{} & \multicolumn{2}{|c|}{$2000 \mathrm{rpm}$} & \multicolumn{2}{c}{$8000 \mathrm{rpm}$} \\
& Mean [deg] & RMS [deg] & Mean [deg] & RMS [deg] \\
\hline with $L$ & -0.246 & 4.72 & -0.744 & 5.25 \\
without $L$ & -0.008 & 4.42 & -0.565 & 4.34 \\
\hline
\end{tabular}

\section{$5 \cdot 2$ センサレス制御での回転試験}

次にセンサレス制御での回転試験を行った結果，1800rpm 以上でセンサレス制御に成功した . 図 11 に2000 rpm および 8000rpm でのロータのラジアル方向変位の軌跡を示す . 図の横軸が $x$ 方向の変位, 縦軸が $y$ 方向の変位を 表す . 青色の線がエンコーダを用いて制御したときの軌跡，緑色の線が $L$ を用いたセンサレス制御，赤色の線が $L$ を用いないセンサレス制御の軌跡を表す .センサレス制御においてもエンコーダを用いた場合とほぼ同じように 位置制御が実現できた .

2000rpm および 8000rpm での回転角度の推定結果を図 12 に示す . 図の実線が推定結果 , 破線がエンコーダで測 定した回転角度を表す . 図の上のグラフが角度推定にインダクタンス項 $L$ を含めた場合 , 下のグラフがインダク タンス項を無視した場合の結果である . また表 2 に推定値とエンコーダとの差の相加平均と二乗平均値を示す . こ れらの結果より，2000rpm および 8000rpm ともほぼ正確な角度推定が行えていることが確認できる．また $L$ 項の 有無による推定結果への影響はほぼ無いことが分かる . 


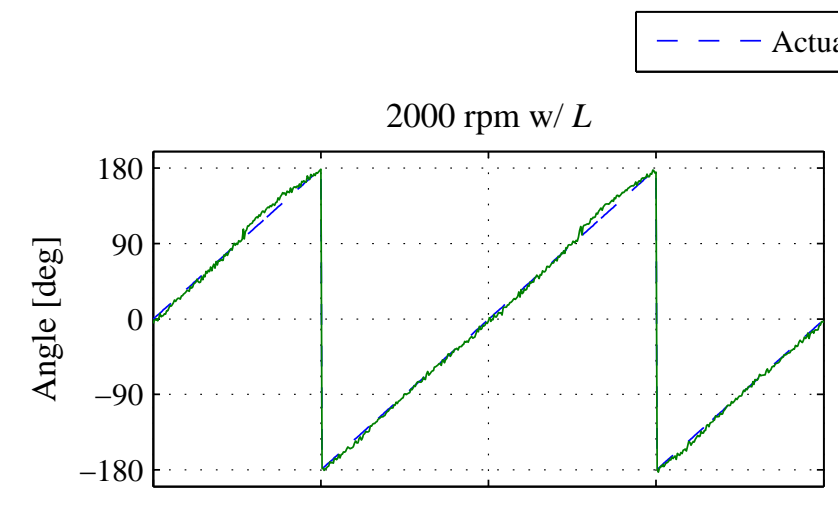

$2000 \mathrm{rpm}$ w/o $L$

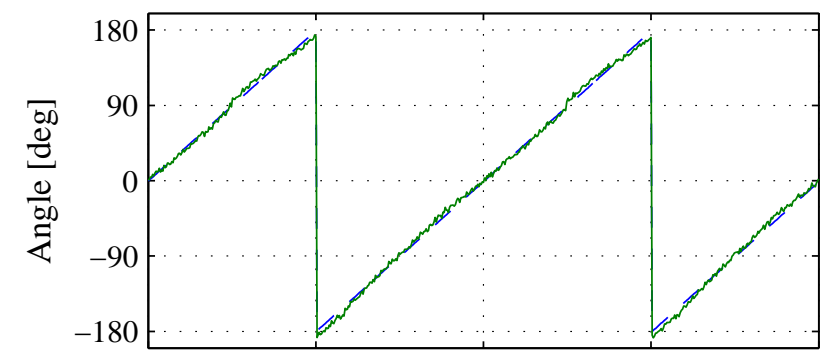

Time [15ms/div]
$8000 \mathrm{rpm} \mathrm{w} / L$

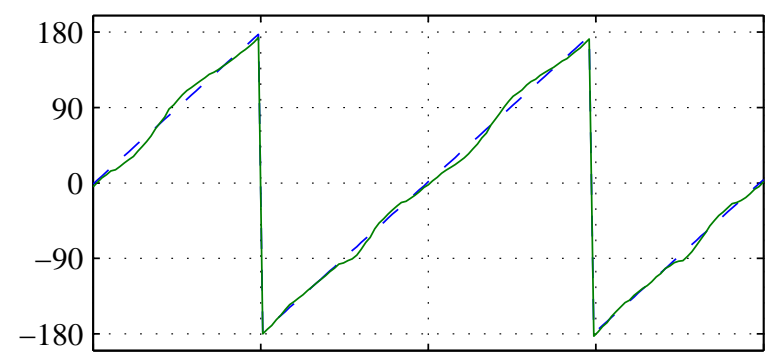

$8000 \mathrm{rpm}$ w/o $L$

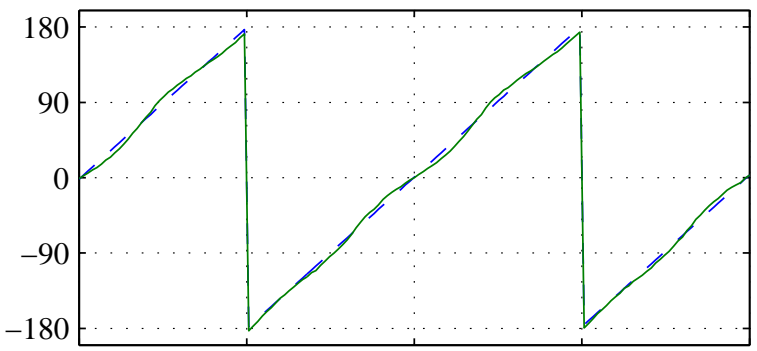

Time [3.75ms/div]

Fig. 12 Estimated rotor angle position. The upper and lower graphs show the results with and without the inductance term. Actual and estimated values are plotted with dashed blue and the solid green lines, respectively.

\section{3 トルク電流およびインダクタンス項の影響}

トルク電流およびインダクタンス項の有無による推定值への影響を調べるため , 一定回転中にトルク負荷を加 え，負荷を与えたときの推定誤差の平均值と二乗平均值を測定した . 3000rpm と 6000rpm での測定結果を図 13 に 示す . 横軸が負荷トルクの大きさ，縦軸が誤差の平均值と二乗平均值である. ○がインダクタンス項がある場合 ×がインダクタンス項が無い場合の結果を示す. 誤差の平均值と二乗平均值は，モータ電流の大きさに影響を受 けるが, 弚の位置制御および回転制御にはほとんど影響せず回転が可能であった . またインダクタンス項の有無 による影響は高回転時に大きくみられた .これはインダクタンス項では電流の微分を用いるためノイズの影響を 受けやすくなること，またインダクタンス項のパラメータ誤差の影響が高回転になるにつれて大きく現れたこと が原因としてと考えられる .ノイズや誤差の影響を完全に取り除くことは難しく，また微分の演算負荷に対して 推定精度の向上効果が得られないため，インダクタンス項を用いずに推定を行った方が良いといえる．

\section{4 抵抗パラメータの影響}

抵抗パラメータによる推定値への影響を調べるため，推定に用いるコントローラの $R$ の值を変更して 3000rpm での角度推定試験を行った . 結果を図 14 に示す. 横軸が負荷トルクの大きさ, 縦軸が誤差の平均値と二乗平均值

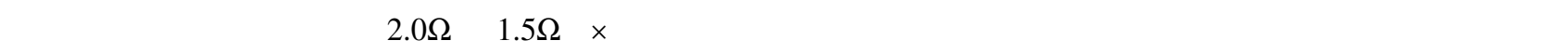
均值は，モータ電流の大きさに影響を受けるものの，位置制御および回転制御にはほとんど影響せず回転が可能 であった . これは抵抗での電圧降下の大きさが逆起電力に比べて小さかったためだと考えられる .この結果より， 本実験装置の場合, 温度上昇などによる抵抗の変動が位置制御に及ぼす影響は小さいと考えられる．また抵抗值 の変動幅に対して, 推定值の変動が均等に生じていないが , これはパワーアンプと電圧センサのチャンネル毎の 特性のずれなどにより，抵抗の実測値よりも小さい值が最適值となったためと思われる .

\section{$5 \cdot 5$ 加減速試験}

エンコーダを用いた場合と推定値を用いた場合について 2000rpm から 8000rpm まで， 8000rpm から 2000rpm ま での加減速試験行った . 結果を図 15 に示す.青線がエンコーダを用いて制御した結果，緑線がセンサレス制御の 

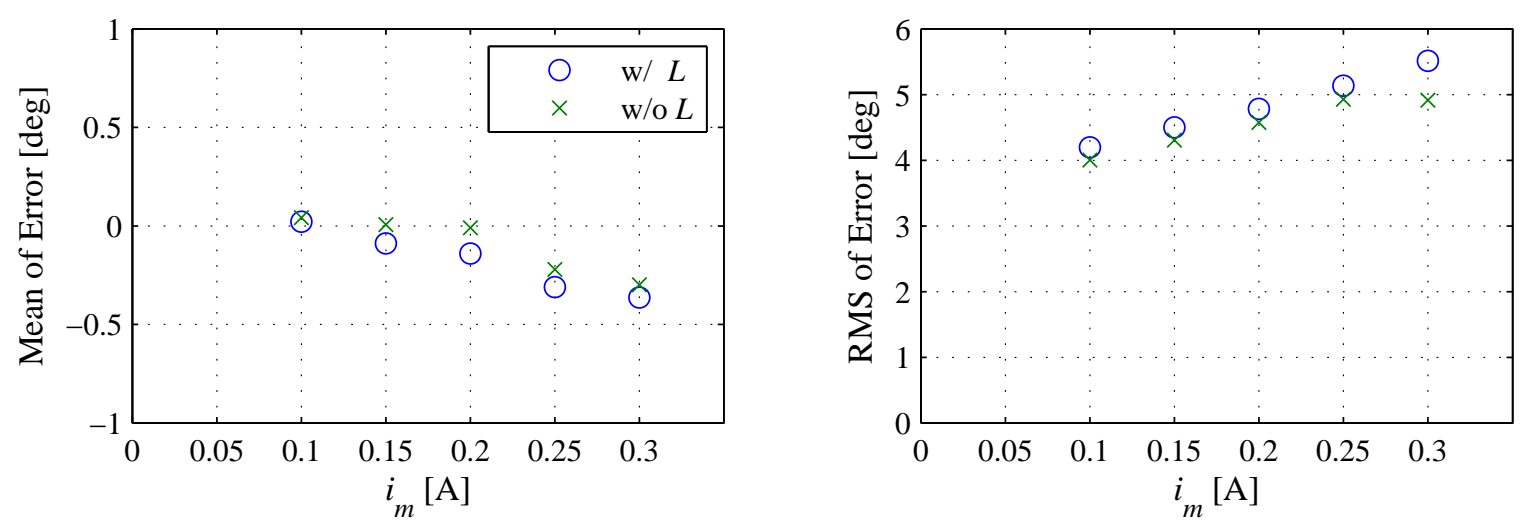

(a) $3000 \mathrm{rpm}$
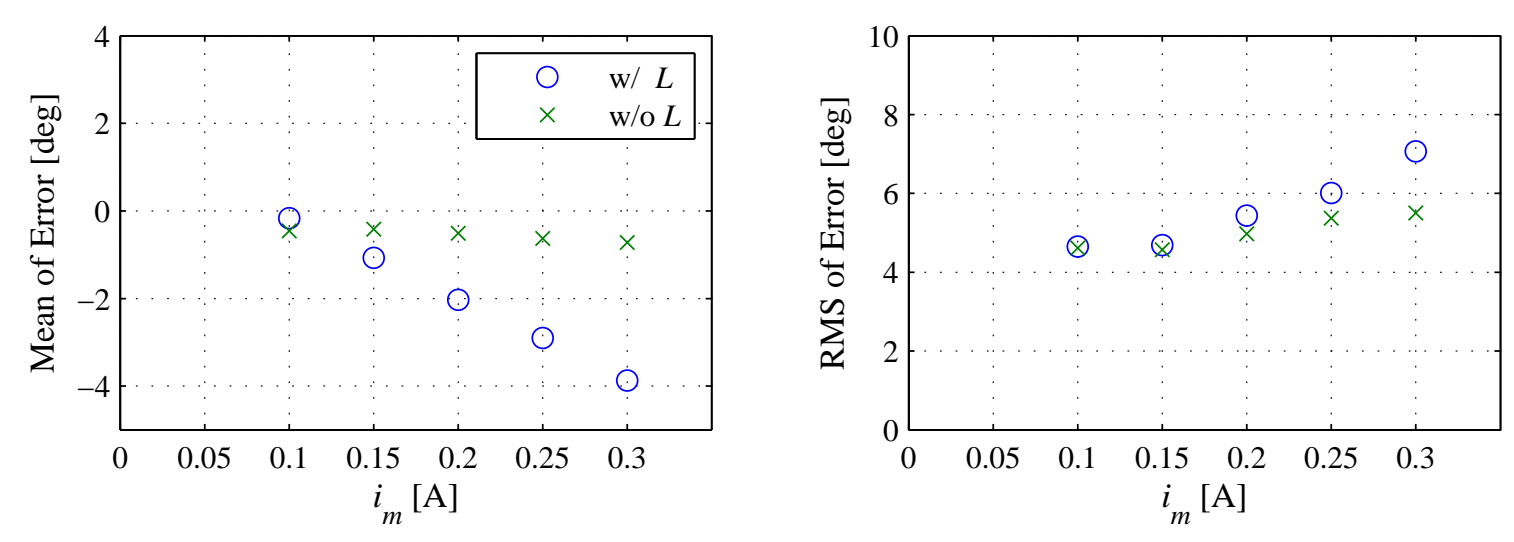

(b) $6000 \mathrm{rpm}$

Fig. 13 Effects on angle by loading. Left and right graphs are means and RMS of angle error. The cases with and without $L$ are plotted with $\bigcirc$ and $\times$.
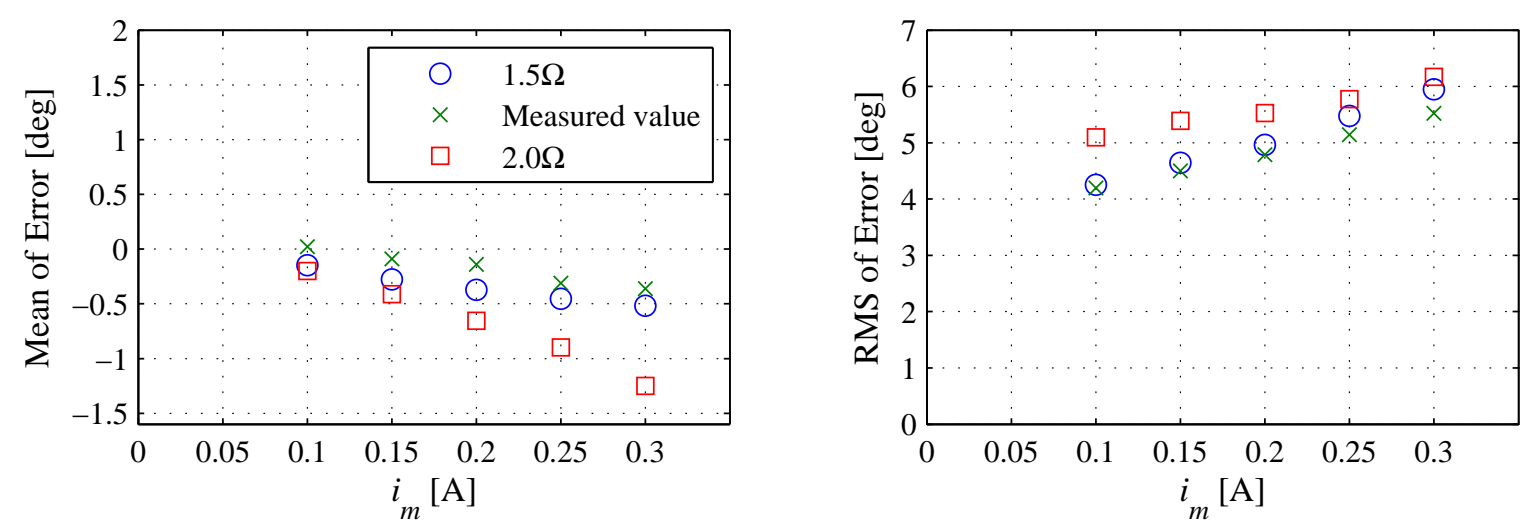

Fig. 14 Effects on angle by resistance values. The resistance are set $2.0 \Omega, 1.5 \Omega$ and measured values

結果を示す.センサレス制御はインダクタンス項の影響を考慮し，ここではインダクタンス項が無い場合のみを 示す.これらの結果から，センサレス制御においてもエンコーダ制御と同じ結果が得られることが確認できた .

本研究で提案する手法では, 2000rpm 以下では回転角度が推定できず，閉ループ制御を用いることができない． そこで2000rpm 以下では開ループ制御（上野，荒川，2011），2000rpm 以上で閉ループ制御に切り替えることで， 0 回転からセンサレス制御が可能となる . 開ループ制御の場合, ステータ電流の位相がロータの角位置に等しいと 近似して制御を行う. 負荷トルクが小さい範囲では実際の角度との差が小さいため, 位置制御が可能となる . 図 16 に $0 \mathrm{rpm}$ から 8000rpm までを 1000rpm ごとに段階的に上げていったときの回転試験の結果を示す . 2000rpm ま では一定の加速度で回転速度を上昇させ，2000rpm に達したときに閉ループ制御に切り替える . 減速時は 2000rpm 


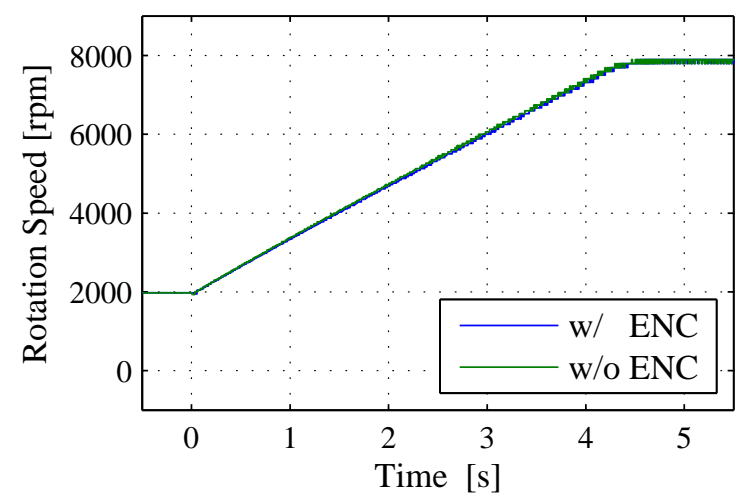

(a) acceleration test

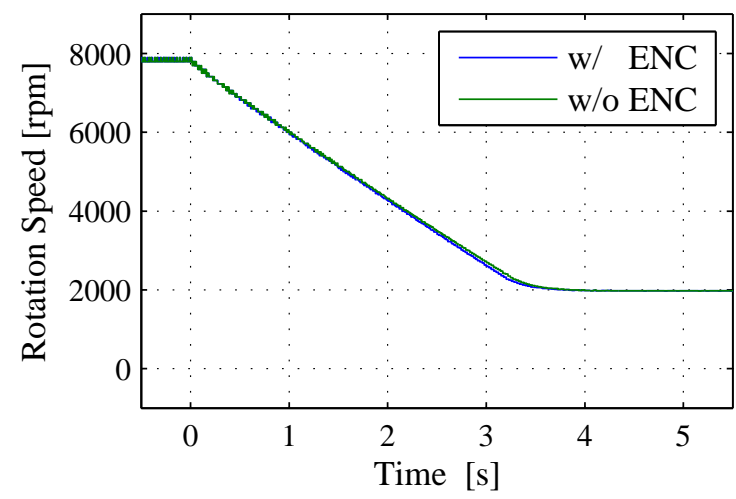

(b) deceleration test

Fig. 15 Acceleration and declaration tests from $2000 \mathrm{rpm}$ to $8000 \mathrm{rpm}$. The results of the sensorless and encoder controller are plotted with the solid blue and green lines

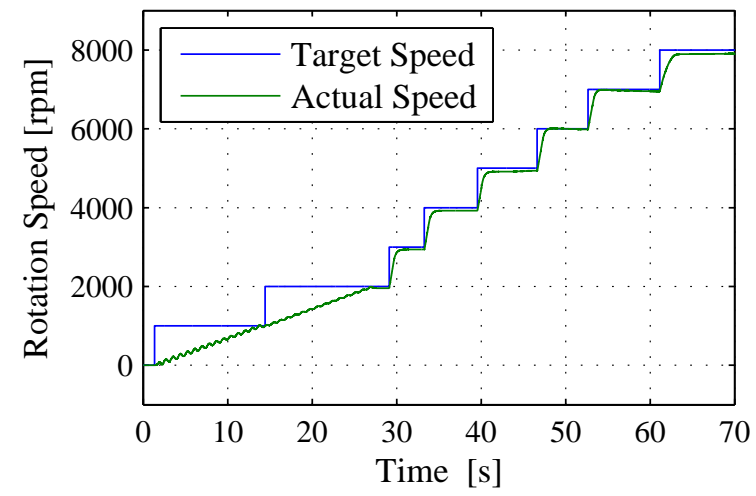

(a) acceleration test

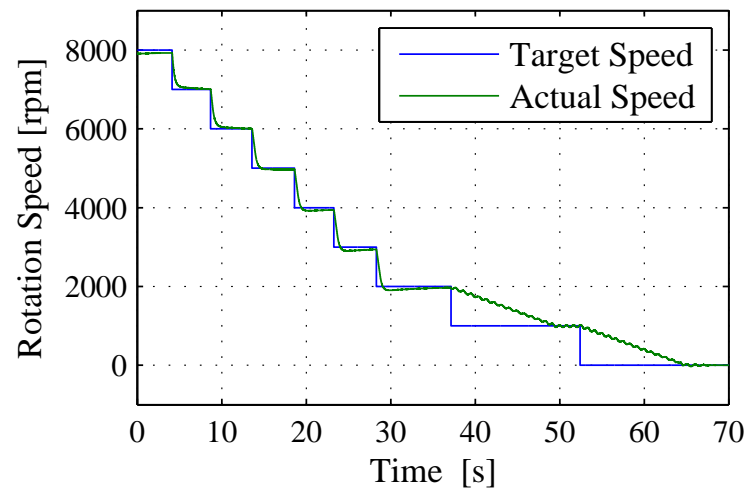

(b) deceleration test

Fig. 16 Acceleration and declaration tests with the combination of open-loop and sensorless controller. The motor is controlled with open-loop less than 2000rpm. When the rotational speed is more than 2000rpm, controller is switched to the sensorless. Target speed and actual speed are plotted with blue and green lines.

まで回転点が落ちてから開ループ制御に切り替える .この結果，角度センサを用いず回転が可能なことが確認で きた .

\section{6. 結言}

本論文では, ローレンツカ型セルフベアリングモータに回転角度のセンサレス制御を導入し，実際に浮上回転 試験を行い, 性能を確認した . 低回転領域では逆起電力が小さいため, 安定した制御が行えなかったが, 1800rpm から正確な回転角度推定が行えた．加減速試験ではセンサレス制御でも，エンコーダ制御とほぼ同じ性能となる ことが確認できた .また開ループ制御と組み合わせることで低回転領域からのセンサレス制御が実現出来ること を示した .

文献

青柳武弘, 青柳滋久, 千葉明, 小型スピンドルドライブ用インバータの誘起電圧を用いた回転角度推定, 電子情報通 信学会技術研究報告 (2002), pp.7-12.

荒川毅郎, 上野哲, ローレンツカを用いたセルフベアリングモータのセンサレス制御, 第 24 回「電磁力関連のダイ ナミクス」シンポジウム, 富山 (2012), pp.429-434.

引原隆士, 木村紀之, 千葉明, 大橋俊介, エース パワーエレクトロニクス (2000), 朝倉書店. 
星野哲馬, 伊藤淳一, 速度センサレスベクトル制御における外乱オブザーバを用いた出力電圧誤差補償, 電子情報通 信学会技術研究報告. ED, 電子デバイス, Vol.108, No.262(2008), pp.63-68.

伊東淳一, 豊崎次郎, 大沢博, 永久磁石同期電動機の V/f 制御の高性能化, 電気学会論文誌 D, 産業応用部門誌, Vol.122, No.3(2002), pp.253-259.

Kanebako , H. and Okada , Y., New design of hybrid type self-bearing motor for high-speed miniature spindle, 8th Int. Symp. on Magnetic Bearings, Mito, Japan(2002), pp.65-70.

加藤貴久, 上野哲, 分布巻線を用いたローレンツ力型磁気軸受の磁気軸受特性と炎の制御, 日本 AEM 学会誌, Vol.17, No.2(2009), pp.240-246.

黑野洋輔, 青柳武弘, 千葉明, 深尾正, コアレスモータの低速度域における回転角度位置センサレス化, 電子情報通信 学会技術研究報告. EE, 電子通信エネルギー技術, Vol.103, No.38(2003), pp.91-96.

並木精密宝石株式会社, <http://www.namiki.co.jp/>, (参照日 2012 年 4 月 25 日).

日本機械学会編, 磁気軸受の基礎と応用 (1995), 養賢堂.

上野哲, 荒川毅郎, スロットレスセルフベアリングモータの非接触浮上回転試験, 日本 AEM 学会誌, Vol.19, No.2(2011), pp.407-413.

\section{References}

Aoyanagi, T., Aoyanagi, S. and Chiba, A., A method of rotor rotational position estimation for small spindle drives using back-EMF, The Institute of Electronics, Information and Communication Engineers Technical Report(2002), pp.7-12 (in Japanese).

Arakawa, T. and Ueno, S., Sensorless control of Lorentz-type self-bearing motor, The 24th Symposium on Electromagnetics and Dynamics, Toyama(2012), pp.429-434 (in Japanese).

Hikihara, T., Kimura, N., Ciba, A. and Ohashi, S., Ace Power electronics (2000), Asakura Publishing Co.,Ltd (in Japanese).

Hoshino, T. and Ito, J., Output voltage correction using a disturbance observer for induction motor drive with speed sensorless vector control, The Institute of Electronics, Information and Communication Engineers Technical Report. ED, Electron Devices, Vol.108, No.262(2008), pp.63-68 (in Japanese).

Ito, J., Toyosaki, J. and Osawa, H., High performance V/f control method for PM motor, The transactions of the Institute of Electrical Engineers of Japan. D, A publication of Industry Applications Society, Vol.122, No.3(2002), pp.253-259 (in Japanese).

Kanebako , H. and Okada , Y., New design of hybrid type self-bearing motor for high-speed miniature spindle, 8th Int. Symp. on Magnetic Bearings, Mito, Japan(2002), pp.65-70.

Kato, T. and Ueno, S., Characteristic of bearing force and its control of Lorentz-Force-Type active magnetic bearing using distributed winding, Transactions of the Japan Society of Mechanical Engineers, Series C, Vol.17, No.2(2009), pp.240-246 (in Japanese).

Kurono, Y., Aoyanagi, T., Chiba, A. and Fukao, T., A development of a rotor rotational position sensorless drive of a coreless motor in low-speed region, The Institute of Electronics, Information and Communication Engineers Technical Report. EE, Energy Engineering in Electronics and Communications, Vol.103, No.38(2003), pp.91-96 (in Japanese).

Namiki Precision Jewel Co.,Ltd(online), available from <http://www.namiki.co.jp/>, (accessed on 25 April, 2012) (in Japanese).

The Japan Society of Mechanical Engineers ed., Fundamentals and applications of magnetic bearings (1995), Yokendo (in Japanese).

Ueno, S. and Arakawa, T., Non-contact rotation test of slotless self-bearing motor, the Japan Society of Applied Electromagnetics and Mechanics, Vol.19, No.2(2011), pp.407-413 (in Japanese). 